\title{
First Record of Dermatophagy by a Smooth-sided Toad, Rhaebo guttatus (Schneider 1799) in Nature
}

\author{
Rawien Jairam ${ }^{1}$, Dick Lock ${ }^{2}$, and Fleur van der Sterren²
}

${ }^{1}$ Vertebrate Department, National Zoological Collection of Suriname, Anton de Kom University, Leysweg-86 (rawien_2000@yahoo.com) ${ }^{2}$ Nature and Wildlife Management, van Hall Larenstein University of Applied Sciences, Leeuwarden,, The Netherlands.

W e herein document the first record of dermatophagy by a Smooth-sided Toad (Rhaebo guttatus) in the wild (Fig. 1). We observed this behavior at the Brownsberg Nature Park (4.94799 $\mathrm{N}, 55.18271^{\circ} \mathrm{W}$; datum WGS 84), Suriname's only nature park that is open and accessible to the general public and national and international researchers. The park lies approximately $130 \mathrm{~km}$ south of the capital, Paramaribo, and consists largely of a lateritic plateau (Norconk et al. 2003).
The shedding, sloughing, or moulting of skin (commonly known as ecdysis) by mature amphibians occurs cyclically, and can last from a few days to several weeks (Vitt and Caldwell 2013). Pre-ecdysis is initiated by the infusion of mucous between living cells deeper in the skin and the stratum corneum (the outermost layer of the skin). This leads to a disruption of linkages that bind the dead cells of the stratum corneum to the deeper skin layers. The skin generally tears mid-dorsally, starting at the head and continuing

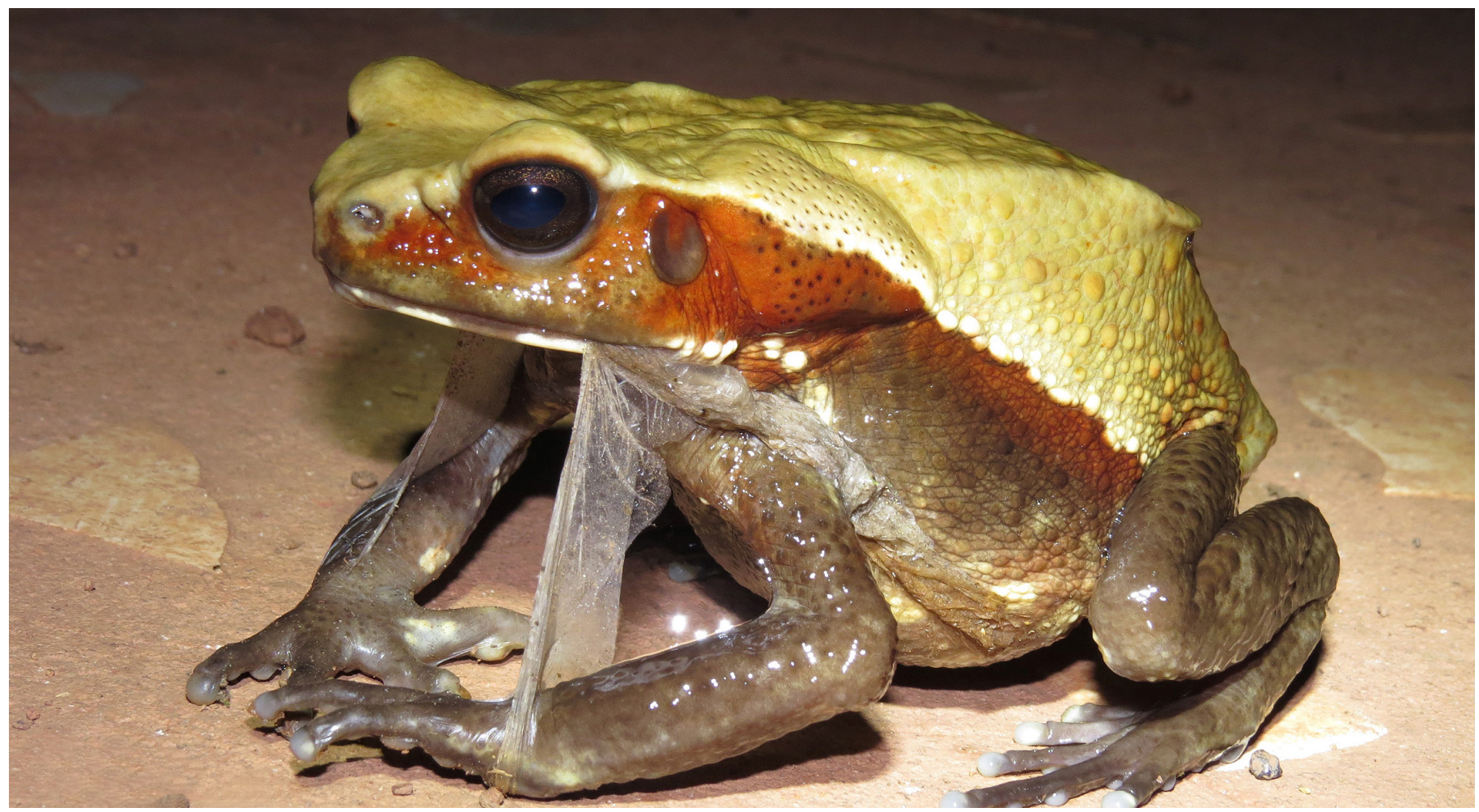

Fig. 1. A Smooth-sided Toad (Rhaebo guttatus) observed pulling and consuming sloughed skin from its forelegs at the Brownsberg Nature Park, Suriname. Photograph (C) D.C. Lock. 
posteriorly. Using its limbs, the amphibian emerges from the old skin, which is frequently consumed (Vitt and Caldwell 2013). Consuming shed skin may replenish some of the proteins present in the skin, although this has yet to be confirmed (Bustard and Maderson 1965). Cramp et al. (2014) also suggested that the sloughing of the skin could be part of an immune response since the process results in an almost onehundred-percent decrease in cutaneous microbial abundance.

Weldon et al. (1993), who used a survey to determine the prevalence of dermatophagy in amphibians and reptiles held in zoos, aquariums, and other collections around the world, documented dermatophagy by Rhaebo guttatus in captivity. That record, however, could be attributable to the lack of a balanced captive diet. Our observation of a shedding toad near one of the tourist lodges in the park supports the contention that this behavior occurs naturally in the wild.

\section{Acknowledgment}

A draft of this note was reviewed by Sabitrie Jairam-Doerga.

\section{Literature Cited}

Bustard, H.R. and P.F.A. Maderson. 1965. The eating of shed epidermal material in squamate reptiles. Herpetologica 21: 306-308.

Cramp R.L., R.K. McPhee, E.A. Meyer, M.E. Ohmer, and C.E. Franklin. 2014. First line of defence: The role of sloughing in the regulation of cutaneous microbes in frogs. Conservation Physiology 2(1): cou012; doi:10.1093/conphys/ cou012.

Norconk M.A., M.A. Raghanti, S.K. Martin, B.W. Grafton, L.T. Gregory, and B.P. de Dijn. 2003. Primates of Brownsberg Natuurpark, Suriname, with particular attention to the pitheciins. Neotropical Primates 11: 94-100.

Vitt L.J. and J.P. Caldwell. 2013. Herpetology: An Introductory Biology of Amphibians and Reptiles. 4th ed. Academic Press, San Diego, California.

Weldon P.J., B.J. Demeter, and R. Rosscoe. 1993. A survey of shed skin-eating (dermatophagy) in amphibians and reptiles. Journal of Herpetology 27: 219228. 